Brit. J. industr. Med., 1953, 10, 101.

\title{
PNEUMOCONIOSIS OF COAL MINERS IN SCOTLAND
}

BY

\author{
JOHN BLACK \\ From the Pneumoconiosis Medical Panel, Ministry of National Insurance
}

(RECEIVED FOR PUBLICATION JULY 21, 1952)

There is ample evidence to prove that pneumoconiosis occurs among coal miners in all the British coalfields but so far detailed information has been almost entirely restricted to South Wales and to a recent study by McCallum (1952) in North-East England.

This paper presents some recent experience of the disease among coal miners in Scotland based on the records of the Pneumoconiosis Medical Panel (previously the Medical Board for Silicosis and Asbestosis) of the Ministry of National Insurance. The records were compiled from examinations made between 1944 and 1949 of persons claiming benefit for disablement due to pneumoconiosis.

Mine dust is a complex mixture of minerals derived from the disintegration of the coal and the rocks in which it occurs. As these minerals are not uniform in composition throughout the coal measures of Great Britain, miners may be exposed to the inhalation of dust of varying composition. This fact alone may have an important influence in determining the incidence and type of pneumoconiosis among workmen in different mining occupations and areas.

\section{Geography and Geology of the Scottish Coalfields}

Practically all the workable coals in Scotland occur in the carboniferous formation within the Midland Valley (central Scotland) and in the Sanquhar-Kirkconnel basin in Dumfriesshire. Small areas of workable coals are found at Machrihanish in the Canonbie district on the Solway Firth and at Brora in Sutherlandshire, but as no cases of pneumoconiosis from these detached areas have arisen in the present series they will not be considered (Scottish Home Department, 1944).

The coalfields of Scotland have been grouped into broad divisions in Fig. 1. Their subdivisions are described in an appendix.

All the workable coals in the Scottish coalfields occur in the carboniferous formation, the subdivisions of which from surface level downwards are as follows :-

\section{Coal measures}

(a) Barren red measures

(b) Productive coal measures

Millstone grit

Carboniferous limestone series
(a) Upper limestone group
(b) Limestone coal group
(c) Lower limestone group

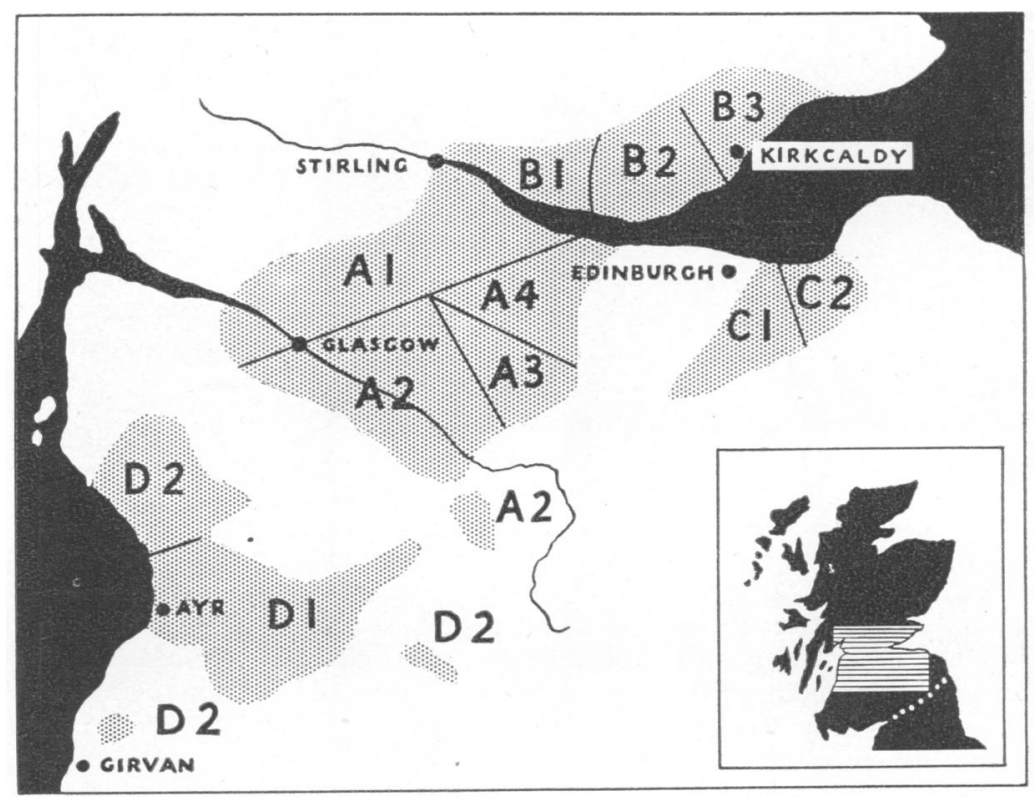

FIG. 1.-The coalfields of Scotland.

101 


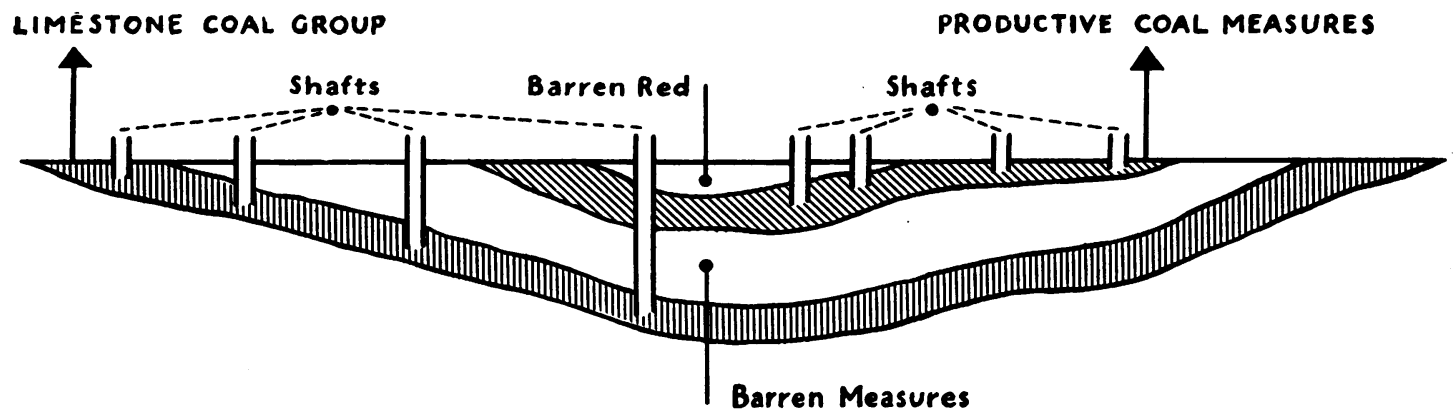

Fig. 2.-Diagram of the valuable seams of coal and of the barren measures.

The valuable seams of coal occur in the productive coal measures and in the limestone coal group. Any coals in the intervening strata, that is in the millstone grit and upper limestone group, are not worked and are designated barren measures (Fig. 2). Some of the coalfields and areas contain both series of coal-bearing rocks. In some districts the workable seams lie at shallow depths while in others they have to be worked at much greater depths.

No significant geological differences in rock formation would be encountered in extracting coal from the productive coal measures and the limestone coal group (Macgregor, personal communication). But in certain districts and collieries and even in different seams in the same colliery, work in thin seams, necessitating brushing the roof or pavement, and faults requiring more mine driving to follow the seams of coal, may add considerably to the silica content of the dust.

\section{Definitions}

Since 1928 when legislative provision was first made for the payment of compensation to coal miners disabled by silicosis there have been several changes in the law (Sutherland, 1949). But in the present study the disease was recognized as pneumoconiosis as defined in the Coal Mining Industry (Pneumoconiosis) Compensation Scheme, 1943, namely, " fibrosis of the lungs due to silica dust ... or other dust and includes the condition of the lungs known as dust reticulation". As the review relates to the years 1944-49 this, in effect, means all applications from coal miners made in pursuance of the above scheme, or the National Insurance (Industrial Injuries) Act, 1946. There are differences in procedure between these two enactments, but from the medical point of view the definition of the disease is the same and disablement arising from the disease can be recorded on a similar basis. In assessing disablement the effects of tuberculosis accompanying pneumoconiosis are reckoned as those of pneumoconiosis.

It was also necessary to ensure that all men included in the survey could rightly be assigned to coal mining in the Scottish Area. The records showed that in the specified six-year period 1,953 claimants were examined by the Medical Panel under the two schemes named above. Thirty-nine men who made claims had had substantial exposure to dust outside the coal mining industry in such occupations as stone-quarrying, foundry work, and shale mining, or had been employed for considerable periods in coal mines outside Scotland. They have been excluded from this study, thus reducing the total to 1,914 persons, of whom 1,315 were certified to be suffering from pneumoconiosis. While some of these had been employed temporarily in surface occupations all had engaged mainly in underground work.

During the period some workmen had two or more examinations, either because of a previous refusal by the Medical Panel to grant a certificate or for reassessment of the degree of disability. These cases were allocated to the year in which a certificate was granted.

The numbers of certifications are shown in Table 1.

TABLE 1

CERTIFICATIONS BY YEAR AND COALFIELD

\begin{tabular}{c|c|c|c|c|c}
\hline \multirow{2}{*}{ Year } & \multirow{2}{*}{$\begin{array}{c}\text { Scottish } \\
\text { Area }\end{array}$} & \multicolumn{3}{|c|}{ Coalfield } \\
\cline { 2 - 5 } & A & B & C & D \\
\hline 1944 & 76 & 40 & 15 & 9 & 12 \\
\hline 1945 & 125 & 75 & 17 & 20 & 13 \\
\hline 1946 & 154 & 96 & 24 & 26 & 8 \\
\hline 1947 & 292 & 196 & 31 & 39 & 26 \\
\hline 1948 & 289 & 171 & 48 & 38 & 32 \\
\hline 1949 & 379 & 245 & 44 & 47 & 43 \\
\hline $1944-1949$ & 1,315 & 823 & 179 & 179 & 134 \\
\hline
\end{tabular}


During this period there has been a considerable and progressive increase in the number of men certified in all four main coalfields. This increase, however, is not uniform throughout the coalfields, for, whereas the increase in $\mathrm{A}$ is six times and in C is five times, in B and D the increases are threefold.

As explained, these cases represent only those dealt with under the Coal Mining Industry (Pneumoconiosis) Compensation Scheme, 1943, and the National Insurance (Industrial Injuries) Act, 1946. However, there were a number of additional certifications arising out of previous schemes.

TABLE 2

ALL CERTIFICATIONS FOR THE SCOTTISH AREA FOR 1939 TO 1949

\begin{tabular}{c|c|c|c|c|c|c|c}
\hline Year & 1939 & 1940 & 1941 & 1942 & 1943 & & $1939-43$ \\
\hline $\begin{array}{c}\text { Number of } \\
\text { certifications }\end{array}$ & 7 & 2 & 3 & 6 & $10^{6}$ & & 28 \\
\hline Year & 1944 & 1945 & 1946 & 1947 & 1948 & 1949 & $1944-49$ \\
\hline $\begin{array}{c}\text { Number of } \\
\text { certifications }\end{array}$ & 109 & 148 & 166 & 322 & 317 & 419 & 1,481 \\
\hline
\end{tabular}

6 for 1943 represents cases of silicotic type.

Table 2 shows all certifications for the years 193949. In the Various Industries (Silicosis) Scheme, 1931, the definition of silicosis was considerably narrower than that of pneumoconiosis given above, and in the Pneumoconiosis (Benefit) Scheme, 1943, it was required that the claimant should be totally disabled by pneumoconiosis.

Since the Coal Mining Industry (Pneumoconiosis) Compensation Scheme became effective on July 1, 1943 , this year may be accepted as a natural division. Accordingly the above figures reveal that the mean annual number of certifications for the five years 1939-43 was $5 \cdot 6$, whereas for the six years $1944-49$ it was 247 , an increase of 44 times. According to Fletcher (1948) the mean annual number of certificates of South Wales coal miners since 1942 up to and including 1946 has risen to four or five times the rate in 1942. From our data the corresponding increase in the Scottish area in the same years is 18 times. The increase in Scotland started suddenly in 1944 and has continued since. It is of interest and importance to consider the possible reasons for this increase.

With the introduction of the Coal Mining Industry (Pneumoconiosis) Compensation Scheme, 1943 , and the prescription of dust reticulation an almost immediate increase was to be expected. In other words, many workmen suffering from disabling chronic pulmonary disease due to dust but not amounting to silicosis, who, before 1943 would have failed to obtain a certificate, now succeeded because of the wider definition of the disease. Few new applications arose in the first six months of the scheme, possibly due to the fact that workmen and doctors required some time to become fully aware of the new legislation.

Also, in order that a workman should be enabled to benefit under the new scheme, it was necessary that he should have been employed in or about a coal mine on or after July 1, 1943. The National Insurance (Industrial Injuries) Act, 1946, further facilitated applications by remitting all fees payable by the claimant and by rescinding the provisions as to compulsory suspension from work on certification except in cases in which the pneumoconiosis was accompanied by tuberculosis. Furthermore, the payment of disablement benefit was not conditional as hitherto on loss of earnings.

That the increase was not entirely due to the inclusion of dust reticulation is suggested by taking account of cases occurring in the years $1944-49$, in which (Table 3) the radiographic appearances

TABLE 3

CASES OF SILICOTIC TYPE

\begin{tabular}{cc|c|c|c|c|c|c|c}
\hline $\begin{array}{c}\text { Certification in } \\
\text { suance of .. }\end{array}$ &.. & 1944 & 1945 & 1946 & 1947 & 1948 & 1949 & $1944-49$ \\
\hline V.I.(S) S 1931 &.. & 10 & 13 & 6 & 27 & 8 & 12 & 76 \\
\hline P (B) S 1943.. &.. & 4 & 3 & 4 & 6 & 4 & 2 & 23 \\
\hline $\begin{array}{l}\text { CMI (P) CS 1943 } \\
\text { N.I.(I.I.)A.1946) }\end{array}$ & 30 & 48 & 68 & 90 & 92 & 92 & 420 \\
\hline \begin{tabular}{l} 
Total (all schemes).. \\
\hline
\end{tabular} & 44 & 64 & 78 & 123 & 104 & 106 & 519 \\
\hline
\end{tabular}

V.I.(S) S $1931=$ Various Industries (Silicosis) Scheme, 1931. P (B) S $1943=$ Pneumoconiosis (Benefit) Scheme, 1943. CMI (P) CS 1943 - Coal Mining Industry (Pneumoconiosis) Compensation Scheme, 1943. N.I.(I.I.) A. $1946=$ National Insurance (Industrial Injuries) Act, 1946.

revealed changes more advanced than dust reticulation and which, under any of the compensation schemes relating to coal miners, would have been interpreted and certified as silicosis.

This represents a mean annual number of certifications by reason of silicosis of 86.5 for the years 1944-49 as against 48 for the years 1939 to 1943 (see Table 2), which is an increase of 18 times. Thus it would appear that 519 , or $35 \%$, of the 1,481 total certifications under all schemes among coal miners in Scotland in the years 1944-49 can be accounted for by patients with silicosis to whom a certificate would have been granted even if the legislation had not been extended to include dust reticulation. This is if anything an underestimate, as doubtful or borderline cases have not been included.

Certain factors which, by stimulating applications, may have given rise to an apparent increase in the 
frequency of the disease should be mentioned. There is no doubt that a number of older miners and others whose physical capacity for work was impaired patriotically carried on during the war. Subsequently they began to leave the mines and made application for certificates of disablement. Again the exhaustion of coal workings, for example in central Lanarkshire, led to some pits being closed with the result that men in impaired health who were able to continue working in their own pits found the effort of starting off in a new district beyond their capacity. This had the effect of bringing such cases forward for certification. Then, during the last few years facilities for radiological examination of the chest at hospitals and in mass radiography surveys had greatly extended and was the means of discovering some unsuspected cases of the disease.

However, even when due allowance is made for these influences it seems reasonable to suggest that there has been a true increase in the occurrence of pneumoconiosis in the Scottish coalfields during recent years. As has been shown above, a definite rise in the number of certifications showing the silicotic type of disease has taken place. Moreover, as on first examination by the Medical Panel about one-half of all these persons was judged to be totally disabled and the remainder showed definite impairment of physical capacity for work, it is probable that the application for a certificate was determined by illness and not by any accidental discovery.

\section{Incidence of Pneumoconiosis}

Fletcher and Oldham (1949) have emphasized the errors of interpretation which occur in the radiological diagnosis of pneumoconiosis, and Cochrane (1951) has discussed the disparity between certification rates and true prevalence rates simply because affected men may continue to work without seeking examination. With these two sources of error the certification rate cannot reflect the true incidence of the disease. But over a number of years, other factors remaining constant, it should be an index of disabling disease. (Certification rate is here used to mean the annual number of certifications per 1,000 underground workers.) The rates are based on populations underground in 1944. It is assumed that these populations did not change substantially during the period under review (Table 4). For the whole of Scotland the rate rises from 1.21 in 1944 to 6.06 in 1949 with a mean annual rate for the years 1944-49 of 3.50. When the total number of certifications under all schemes is taken into consideration the corresponding figures are $1.74,6.69$, and 3.95 respectively.
TABLE 4

MEAN ANNUAL CERTIFICATION RATES PER 1,000 UNDERGROUND WORKERS IN THE SEPARATE SCOTTISH COALFIELDS AND SUBDIVISIONS

\begin{tabular}{cc|c|c|c}
\hline $\begin{array}{c}\text { Coalfield } \\
\text { or District }\end{array}$ & $\begin{array}{c}\text { Underground } \\
\text { Workers }\end{array}$ & $\begin{array}{c}\text { Number of } \\
\text { Certificates }\end{array}$ & $\begin{array}{c}\text { Certificate Rate } \\
\text { Mean 1944-1949 }\end{array}$ \\
\hline Scotland . . & 62,553 & 1,315 & $3 \cdot 50$ \\
\hline A .. & $\ldots$ & 29,744 & 823 & $4 \cdot 61$ \\
A1 & $\ldots$ & 8,646 & 119 & $2 \cdot 29$ \\
A2 & $\ldots$ & 10,889 & 319 & $4 \cdot 88$ \\
A3 & $\ldots$ & 4,624 & 273 & $9 \cdot 84$ \\
A4 & $\ldots$ & 5,585 & 112 & $3 \cdot 34$ \\
\hline B . & $\ldots$ & 15,251 & 179 & $1 \cdot 96$ \\
B1 & $\ldots$ & 2,582 & 32 & $2 \cdot 06$ \\
B2 & $\ldots$ & 7,589 & 121 & $2 \cdot 66$ \\
B3 & $\ldots$ & 5,080 & 26 & $0 \cdot 85$ \\
\hline C . & $\ldots$ & 7,999 & 179 & $3 \cdot 73$ \\
C1 & $\ldots$ & 5,226 & 77 & $2 \cdot 44$ \\
C2 &.. & 2,773 & 102 & $6 \cdot 13$ \\
\hline D & $\ldots$ & 9,559 & 134 & $2 \cdot 34$ \\
D1 & $\ldots$ & 7,456 & 91 & $2 \cdot 03$ \\
D2 & $\ldots$ & 2,103 & 43 & $3 \cdot 41$ \\
\hline & & & & \\
\hline
\end{tabular}

A considerable variation in the mean annual certification rate for the years 1944-49 is found between the separate coalfields ranging from 4.61 in $\mathrm{A}$ to 1.96 in $\mathrm{B}$.

If these figures are further broken down into districts within the separate coalfields the variation in certification rates is even more striking. Districts A 3 and $C 2$ have high certification rates of 9.84 and 6.13 respectively and $\mathrm{B} 3$ the lowest rate of 0.85 . The possible causes for these large differences must be considered.

Geological Formation.-Area B3 and coalfield D are essentially productive coal measures, yet the mean annual certification rates differ as between 0.85 and 2.34 . Similarly in areas $\mathrm{A} 1, \mathrm{~B} 2$, and $\mathrm{C} 2$, which are essentially of the limestone coal group, the respective rates are $2 \cdot 29,2 \cdot 66$, and $6 \cdot 13$. Then comparing coalfield $\mathrm{D}$, which is $93.2 \%$ productive coal measures, with area A1, which is $92.5 \%$ limestone coal group, and both involving comparable numbers of workmen, the certification rates are almost identical, 2.34 and 2.29 respectively. The workmen with few exceptions had spent the whole of their working lives in a single area and so the incidence of disease should reflect the dust hazards of the coal measures of that area.

Thus it seems that geological formation does not play any material part in the varying incidence of pneumoconiosis in the different areas of the Scottish coalfields. This is in keeping with the information recorded earlier that there are no significant geological differences between the productive coal measures 
and the limestone coal group such as would result in any material differences in the quality of airborne dust to which these separate groups of miners are exposed.

Dustiness of Mines.-Sir Andrew Bryan (1949, 1950) H.M. Chief Inspector of Mines, has emphasized the important part played by the increased production of dust which has resulted from greater mechanization in mines. But mechanization itself is not the only factor affecting the production of dust. Jenkins (1948) states that the progress of mechanization in the South Wales coalfield, where the incidence of certified cases far exceeds that of all other areas (Fletcher, 1948), has proceeded much more slowly than in other parts of Great Britain. $\mathrm{He}$ attributes the high incidence of pneumoconiosis in South Wales coal miners to the dry, dusty conditions prevailing there.

Other factors which probably affect the dustiness of a mine are thinness of the seams and frequent faulting, conditions which are more common in some areas than in others. Not only do they affect the quantity of airborne dust but they alter the quality by increasing the silica content.

With regard to mechanization and the nature of workings, Dr. C. G. Gooding, Divisional Medical Officer, National Coal Board, Scottish Division, gives the following information, some of which has been published in the Ministry of Fuel and Power Statistical Digests for the years 1945-49.

Mechanization.-In 1913 only $8 \%$ of coal in Great Britain was machine-cut. At this date the corresponding figure for Scotland was $22 \%$ and most of this was in thin seams in the Lanarkshire coalfield. Indeed, Lanarkshire is reputed to be the home of the coal-cutter. During the ensuing 15 years there was a general expansion but the relative positions recorded above were more or less maintained.

Conveyors of bigger capacity were brought into use while machine cutting was extended to thicker seams. In $192812 \%$ of coal in Great Britain was mechanically conveyed ; in Scotland $25 \%$. Machine cutting was, until about 1930 , much more general in
Lanarkshire, and in the early years the disc cutter was in common use. It is said that about 30 years ago it used to be asked by miners in Muirkirk (Ayrshire), "Who is going to Shotts, to be poisoned ?" This apparently referred to the fact that men returning from Shotts, where the disc cutter was used, were noted to be short of breath when they got back to Muirkirk, where the coal was hand-got by stoop and room methods.

Table 5, setting out the percentage of machinecut coal, emphasizes that the mechanical cutting of coal in Lanarkshire and Fife and Clackmannan is substantially higher than in the other Scottish coalfields and in the rest of Great Britain. Nevertheless the certification rates do not appear to be parallel to the degree of mechanization, for whereas the certification rate in coalfield A (Lanarkshire) is 4.61 , that in coalfield B (Fife and Clackmannan) is 1.96. On the other hand in the less mechanized coalfields the certification rates are intermediate between these. This would support the suggestion that mechanization per se is not the only factor in determining the certification rate in individual areas.

Other factors which can influence the incidence of pneumoconiosis are the awareness of miners and their medical attendants of the disease and of the legislative provisions for its compensation and of the age distribution of the workers at risk. It is not possible to assess the effect of the latter, but the officials of the National Union of Mine Workers are of the opinion that in all districts in Scotland there is a general awareness of the procedure with regard to claims.

\section{Pneumoconiosis in Individual Collieries}

An attempt was made to elucidate this point by scrutinizing the occupational histories of the 1,315 certified cases. Before any certified case was allocated to a particular colliery it was required that certain conditions should be fulfilled : (1) that all the colliery work had been carried out at one colliery ; or (2) that 30 years or more of the latest exposure had been at one colliery ; or (3) if employment amounted to less than $\mathbf{3 0}$ years that the latest exposure at one colliery had amounted to at least

TABLE 5

PERCENTAGE OF MACHINE-CUT COAL PRODUCTION

\begin{tabular}{|c|c|c|c|c|c|c|c|c|c|c|c|c|c|}
\hline \multirow{2}{*}{\multicolumn{4}{|c|}{ District }} & \multicolumn{10}{|c|}{ Year } \\
\hline & & & & 1938 & 1939 & 1940 & 1941 & 1942 & 1943 & 1944 & 1945 & 1946 & 1947 \\
\hline $\begin{array}{l}\text { Fife and Clackmannan } \\
\text { Lothians-Mid and East } \\
\text { Lanarkshire . . } \\
\text { Ayr and Dumfries } \\
\text { Great Britain.. }\end{array}$ & $\begin{array}{l}\because \\
\because \\
\because\end{array}$ & $\begin{array}{l}. . \\
\because \\
\cdots\end{array}$ & $\begin{array}{l}\ldots \\
\because \\
\cdots\end{array}$ & $\begin{array}{l}90 \\
62 \\
84 \\
69 \\
59\end{array}$ & $\begin{array}{l}89 \\
65 \\
84 \\
70 \\
61\end{array}$ & $\begin{array}{l}91 \\
65 \\
84 \\
70 \\
64\end{array}$ & $\begin{array}{l}91 \\
65 \\
86 \\
72 \\
66\end{array}$ & $\begin{array}{l}91 \\
68 \\
85 \\
72 \\
66\end{array}$ & $\begin{array}{l}92 \\
66 \\
85 \\
74 \\
69\end{array}$ & $\begin{array}{l}93 \\
69 \\
90 \\
74 \\
72\end{array}$ & $\begin{array}{l}92 \\
72 \\
89 \\
77 \\
72\end{array}$ & $\begin{array}{l}93 \\
74 \\
88 \\
76 \\
74\end{array}$ & $\begin{array}{l}92 \\
74 \\
90 \\
72 \\
75\end{array}$ \\
\hline
\end{tabular}


$75 \%$ of the total exposure, with a minimum of 2.0 years.

The Coalfields Report (1944) lists 221 collieries in the Scottish area and from these during the six years 1944-49 1,315 workmen were granted certificates. Only 166 workmen fulfilled the criteria defined for attachment to an individual colliery and these were derived from no less than 75 collieries.

It was found that of 39 collieries each had only one certified case which could reasonably be attributed to work in them ; 12 collieries had more than three cases but one had 12 cases. Altogether only three collieries had more than an average of one certified case per annum. The numbers of underground workers at these three collieries were 214,347 , and 666 , and the certifications over the six years numbered seven, nine, and 12 respectively. This emphasizes how difficult it is to use certification figures to determine the relative risks of separate pits.

\section{Age and Years of Employment}

The age here is taken as that at the date of first certification. No attempt is made to estimate the relative incidence of the disease in different age groups as this would involve knowledge of the population at risk at these ages, a matter on which no data are available for the period surveyed.

Only $2.4 \%$ of certifications occur under the age of 41 years (Table 6). Disabling disease occurs almost

TABLE 6

CERTIFICATIONS BY AGE GROUP AND PERIOD OF EMPLOYMENT

\begin{tabular}{c|r|r|r|r|r}
\hline \multirow{2}{*}{ Age Group } & \multicolumn{2}{|c|}{ Certifications } & \multirow{2}{*}{ Years of Employment } & \multicolumn{2}{|c}{ Certifications } \\
\cline { 2 - 6 } & No. & \multicolumn{1}{|c}{ No. } & \multicolumn{1}{c}{$\%$} \\
\hline 30 and under & 0 & $0 \cdot 0$ & 20 and under & 6 & $0 \cdot 5$ \\
\hline $31-40 . . \quad$. & 30 & $2 \cdot 4$ & $21-30$ & 184 & $14 \cdot 0$ \\
\hline $41-50 \ldots \quad .$. & 299 & $22 \cdot 7$ & $31-40$ & 513 & $39 \cdot 0$ \\
\hline $51-60 \ldots \quad .$. & 553 & $42 \cdot 0$ & $41-50$ & 421 & $32 \cdot 0$ \\
\hline 61 and over.. & 433 & $33 \cdot 0$ & 51 and over & 191 & $14 \cdot 5$ \\
\hline All ages.. & 1,315 & $100 \cdot 0$ & Total & 1,315 & $100 \cdot 0$ \\
\hline
\end{tabular}

entirely in middle life or later. Most of the men had spent their whole working lives from the age of 14 years and even earlier in the mines, although for some the period had been interrupted by service in H.M. Forces during the first world war. A few had worked for short periods in non-mining occupations. In computing the period of employment in mining these extraneous occupations have been excluded. Table 6 also indicates that the disease is seldom manifest under 21 years of coal-mining employment.

The percentage of certifications after the age of 60 years in coalfields $A(35 \cdot 5)$ and $D(40 \cdot 3)$ is greater than in coalfields $B(25 \cdot 2)$ and $C(23 \cdot 5)$. If the individual years are considered a definite trend is apparent. The number of certifications and the percentage of each year's total has steadily advanced in the older age group, ranging among men over the age of 60 years from 11 or $14.7 \%$ in 1944 to 152 or $39.9 \%$ in 1949 . Coalfields $A$ and D have a definitely higher percentage of the total certifications in this advanced group than have coalfields B and C. Lanarkshire (A) and Ayrshire (D) are the oldest coal-mining areas and in recent years there has been a considerable decline of mining in the former. Closing the pits has displaced miners, many of whom felt disinclined and indeed were unfit for work elsewhere.

\section{Type of Pneumoconiosis}

Davies and Mann (1949) devised a radiological classification in which simple pneumoconiosis and complicated pneumoconiosis are recognized as the two main types of the disease In simple pneumoconiosis the $x$-ray appearances are considered to represent actual dust accumulation in the lungs together with localized foci of fibrosis, reticulation, and nodulation. In complicated pneumoconiosis the $x$-ray appearances are considered to represent dust accumulation and massive fibrosis due to the action of dust alone or in association with tuberculous infection. Evidence has been adduced by Fletcher (1948) and Gough (1949) to show that complicated pneumoconiosis appears only as a result of associated infection, probably tuberculous, in lungs already occupied by dust. Moreover, Fletcher (1950), as a result of a series of researches, has concluded that massive fibrosis develops only on a basis of antecedent simple pneumoconiosis of category 2 or more.

Our personal experience is that radiological appearances of pneumoconiosis among coal miners in Scotland conform closely to those described by Davies and Mann in South Wales coal miners. Accordingly in this discussion simple pneumoconiosis and complicated pneumoconiosis bear the meaning attached to them by these authors.

Of the 1,315 certified cases, 358 or $27 \cdot 2 \%$ were diagnosed as complicated pneumoconiosis (Table 7).

Table 7 shows that throughout the six years 1944 to 1949 there has been a definite increase in the absolute number of certificates given for complicated pneumoconioiss, but simultaneously the proportion of the latter in all certifications in each 
TABLE 7

TOTAL DISABLEMENT AND COMPLICATED PNEUMOCONIOSIS IN SEPARATE YEARS

\begin{tabular}{|c|c|c|c|c|c|}
\hline \multirow{2}{*}{ Year } & \multirow{2}{*}{$\begin{array}{c}\text { Certifica- } \\
\text { tions }\end{array}$} & \multicolumn{2}{|c|}{$\begin{array}{c}\text { Total } \\
\text { Disablement }\end{array}$} & \multicolumn{2}{|c|}{$\begin{array}{c}\text { Complicated } \\
\text { Pneumoconiosis }\end{array}$} \\
\hline & & No. & $\%$ & No. & $\%$ \\
\hline 1944 & 76 & 27 & $35 \cdot 5$ & 27 & $35 \cdot 5$ \\
\hline 1945 & 125 & 31 & $24 \cdot 8$ & 37 & 30.0 \\
\hline 1946 & 154 & 45 & $29 \cdot 2$ & 62 & 40.0 \\
\hline 1947 & 292 & 75 & $25 \cdot 7$ & 78 & 26,7 \\
\hline 1948 & 289 & 64 & $22 \cdot 2$ & 74 & $25 \cdot 6$ \\
\hline 1949 & 379 & 63 & $16 \cdot 2$ & 80 & $21 \cdot 1$ \\
\hline 1944-49 & 1,315 & 305 & $23 \cdot 2$ & 358 & $27 \cdot 2$ \\
\hline
\end{tabular}

year has decreased substantially from 35.5 in 1944 to 21.1 in 1949 . The proportion of all certificates for total disablement has declined in like manner. Complicated pneumoconiosis does not necessarily involve total disablement, and the double trend noted above would suggest that claimants are coming forward more readily at an earlier stage of the disease and before they are wholly incapacitated for work. This was to be expected, especially after July 5, 1948, as certification did not necessarily involve suspension from work and disablement benefit was payable without regard to earnings.

\section{Disablement in Relation to Age}

Table 8 shows that the degree of disability found at the time of first certification increases with the age of the applicant, a relationship which accords with the findings reported by Gilson (1951) in South Wales. This does not mean that age is the only factor involved in determining disability, for when the type of pneumoconiosis is related to the age of the applicant (Table 9) it appears that the percentage incidence of complicated pneumoconiosis progressively rises with age. This suggests that the

TABLE 8

CERTIFICATIONS BY DEGREE OF DISABILITY IN SEPARATE AGE GROUPS

\begin{tabular}{|c|c|c|c|c|c|c|c|c|}
\hline \multirow[t]{2}{*}{ Age Groups } & \multirow[t]{2}{*}{ Total } & \multicolumn{2}{|c|}{$\begin{array}{c}\text { Total } \\
\text { Disable- } \\
\text { ment }\end{array}$} & \multicolumn{2}{|c|}{$\begin{array}{c}\text { Partial } \\
\begin{array}{c}\text { Disable- } \\
\text { ment }\end{array}\end{array}$} & \multicolumn{2}{|c|}{$\begin{array}{c}\text { No } \\
\text { Disable- } \\
\text { ment }\end{array}$} & \multirow[t]{2}{*}{$\begin{array}{l}\text { All } \\
(\%)\end{array}$} \\
\hline & & No. & $\%$ & No. & $\%$ & No. & $\%$ & \\
\hline 30 and under & 0 & 0 & 0.0 & 0 & 0.0 & 0 & 0.0 & $100 \cdot 0$ \\
\hline $31-40$ & 30 & 4 & $13 \cdot 3$ & 16 & $53 \cdot 3$ & 10 & $33 \cdot 3$ & $100 \cdot 0$ \\
\hline$\overline{41-50}$ & 299 & 28 & 9.4 & 234 & $78 \cdot 3$ & 37 & $12 \cdot 4$ & $100 \cdot 0$ \\
\hline$\overline{51-60}$ & 553 & 107 & $19 \cdot 4$ & 424 & $76 \cdot 6$ & 22 & 39 & $100 \cdot 0$ \\
\hline 61 and over.. & 433 & 166 & $38 \cdot 3$ & 259 & $59 \cdot 8$ & 8 & $1 \cdot 8$ & $100 \cdot 0$ \\
\hline$\overline{\text { All ages }}$ & 1,315 & 305 & $23 \cdot 2$ & 933 & $71 \cdot 0$ & 77 & $6 \cdot 0$ & $100 \cdot 0$ \\
\hline
\end{tabular}

TABLE 9

TYPE OF PNEUMOCONIOSIS IN RELATION TO AGE

\begin{tabular}{|c|c|c|c|}
\hline \multirow{2}{*}{ Age Group } & \multirow{2}{*}{$\begin{array}{c}\text { Certifica- } \\
\text { tions }\end{array}$} & \multicolumn{2}{|c|}{ Complicated Pneumoconiosis } \\
\hline & & No. & $\%$ of Age Group \\
\hline $\left.\begin{array}{l}30 \text { and under } \\
31-40 \ldots\end{array}\right\}$ & $\left.\begin{array}{r}0 \\
30\end{array}\right\} 30$ & $\left.\begin{array}{l}0 \\
4\end{array}\right\} 4$ & $\left.\begin{array}{r}0.0 \\
13 \cdot 3\end{array}\right\} 13 \cdot 3$ \\
\hline $\left.\begin{array}{l}41-50 \\
51-60\end{array}\right\}$ & $\left.\begin{array}{l}299 \\
553\end{array}\right\} 852$ & $\left.\begin{array}{r}49 \\
146\end{array}\right\} 195$ & $\left.\begin{array}{l}16.4 \\
26.4\end{array}\right\} 22.9$ \\
\hline 61 and over .. & 433 & 159 & $36 \cdot 7$ \\
\hline All ages & 1,315 & 358 & $27 \cdot 2$ \\
\hline
\end{tabular}

period of exposure to risk, which is reflected by age, may be a factor in the production of complicated pneumoconiosis.

\section{Pneumoconiosis in Separate Mining Occupations}

A number of applicants had been engaged in one type of work long enough to suggest that any pneumoconiotic changes present were probably due to a particular occupation. Four groups were defined, namely, brusher and stoneminer (261), fireman and shotfirer (35), machineman (79), hewer and stripper (187); the remaining 753 had had mixed employment. Although the attack rate of pneumoconiosis in the various groups cannot be calculated, the type of disease found in these occupational groups is of interest (Table 10). Among brushers and stoneminers, that is men whose work is predominantly in stone, the incidence of complicated pneumoconiosis not only increases with age, but is relatively more common at all ages than in the other occupational groups. Thus working in stone may be a further factor in the causation of complicated pneumoconiosis.

Massive fibrosis or complicated pneumoconiosis is a more advanced pathological state than simple pneumoconiosis. In general the more advanced the degree and type of the disease the more advanced the degree of disablement, but Table 11 shows that simple pneumoconiosis may cause total disablement and complicated pneumoconiosis may still be consistent with considerable working capacity.

Complicated pneumoconiosis has in every case been assessed as causing some degree of disablement. Fifty per cent. of the 358 persons suffering from it were certified to be totally disabled; the corresponding figure in respect of the 957 cases of simple pneumoconiosis was only $13 \cdot 2 \%$.

So far, then, the evidence suggests that the period at risk as reflected by age is a factor in the aetiology of massive fibrosis or complicated pneumoconiosis. In individual occupations stone work may be another contributory factor. Throughout the literature reference is always made to the influence of 
TABLE 10

TYPE OF PNEUMOCONIOSIS IN OCCUPATIONAL GROUPS

\begin{tabular}{|c|c|c|c|c|c|c|c|c|c|c|c|}
\hline \multirow{2}{*}{ Age Group } & & \multicolumn{2}{|c|}{$\begin{array}{l}\text { Brusher and } \\
\text { Stoneminer }\end{array}$} & \multicolumn{2}{|c|}{$\begin{array}{l}\text { Fireman and } \\
\text { Shotfirer }\end{array}$} & \multicolumn{2}{|c|}{ Machineman } & \multicolumn{2}{|c|}{$\begin{array}{l}\text { Hewer and } \\
\text { Stripper }\end{array}$} & \multicolumn{2}{|c|}{ Others } \\
\hline & & Cert. & $\%$ C.P. & Cert. & $\%$ C.P. & Cert. & \% C.P. & Cert. & \% C.P. & Cert. & \% C.P. \\
\hline 50 and under & $\ldots$ & 60 & $23 \cdot 3$ & 0 & 0.0 & 27 & $15 \cdot 0$ & 45 & $13 \cdot 3$ & 197 & $14 \cdot 7$ \\
\hline $51-60 \ldots$ & $\cdots$ & 111 & $36 \cdot 0$ & 11 & $27 \cdot 3$ & 38 & $28 \cdot 9$ & 89 & $19 \cdot 1$ & 304 & $25 \cdot 0$ \\
\hline 61 and over.. & $\cdots$ & 90 & $45 \cdot 5$ & 24 & $25 \cdot 0$ & 14 & $35 \cdot 7$ & 53 & $35 \cdot 9$ & 252 & $34 \cdot 7$ \\
\hline All ages & $\ldots$ & 261 & $36 \cdot 0$ & 35 & $25 \cdot 7$ & 79 & $25 \cdot 3$ & 187 & $22 \cdot 7$ & 753 & $25 \cdot 6$ \\
\hline
\end{tabular}

C.P.-Complicated pneumoconiosis.

TABLE 11

TYPE OF PNEUMOCONIOSIS IN RELATION TO DISABLEMENT

\begin{tabular}{|c|c|c|c|c|c|c|c|c|c|c|c|c|}
\hline \multirow{3}{*}{ Age } & \multirow{3}{*}{\multicolumn{2}{|c|}{ Group }} & & \multicolumn{3}{|c|}{ Total Disablement } & \multicolumn{3}{|c|}{ Partial Disablement } & \multicolumn{3}{|c|}{ No Disablement } \\
\hline & & & & \multirow{2}{*}{$\underset{\text { Types }}{\text { All }}$} & \multicolumn{2}{|c|}{$\begin{array}{c}\text { Complicated } \\
\text { Pneumoconiosis }\end{array}$} & \multirow{2}{*}{$\underset{\text { Types }}{\text { All }}$} & \multicolumn{2}{|c|}{$\begin{array}{c}\text { Complicated } \\
\text { Pneumoconiosis }\end{array}$} & \multirow{2}{*}{$\begin{array}{c}\text { All } \\
\text { Types }\end{array}$} & \multicolumn{2}{|c|}{$\begin{array}{c}\text { Complicated } \\
\text { Pneumoconiosis }\end{array}$} \\
\hline & & & & & No. & $\%$ & & No. & $\%$ & & No. & $\%$ \\
\hline$\overline{30 \text { and under }}$ & $\ldots$ & $\ldots$ & $\ldots$ & 0 & 0 & 0.0 & 0 & 0 & 0.0 & 0 & 0 & 0.0 \\
\hline $31-40$ & $\cdots$ & $\cdots$ & $\cdots$ & 4 & 1 & $25 \cdot 0$ & 16 & 3 & $18 \cdot 8$ & 10 & 0 & 0.0 \\
\hline $51-60$ & $\ldots$ & . & . & 107 & 62 & $57 \cdot 9$ & 424 & 84 & $19 \cdot 8$ & 22 & 0 & 0.0 \\
\hline 61 and over & $\ldots$ & $\cdots$ & . & 166 & 102 & $61 \cdot 4$ & 259 & 57 & $22 \cdot 0$ & 8 & 0 & $0 \cdot 0$ \\
\hline All ages .. & $\ldots$ & $\ldots$ & . & 305 & 179 & 58.7 & 933 & 179 & $19 \cdot 2$ & 77 & 0 & 0.0 \\
\hline
\end{tabular}

infection, notably tuberculosis, but relative to the present cases we have no direct information on this aspect of the problem. It is possible, however, to study our cases in conjunction with official statistics on tuberculosis. According to the latest published figures of the Registrar General for Scotland (1936) the comparative mortality rate of coal-mining occupations from all causes is $\mathbf{1 0 8 \cdot 2}$ (base 100). It is stated that this mortality rate is consistently above the average for each age and is largely due to deaths from accidental causes and respiratory diseases. Mining and quarrying occupations are listed among those showing a low mortality rate from tuberculosis (70), but on the other hand these same occupations have a high mortality rate from bronchitis and pneumonia (151).

The proportion of complicated pneumoconiosis in all cases is almost identical in each of the four coalfields, but the mean annual certification rate varies throughout these coalfields (see Table 4). The relation of the certification rates of pneumoconiosis to the death rates for respiratory tuberculosis and for bronchitis and pneumonia in the corresponding areas is shown in Table 12.

In this comparison there is a possible fallacy in that the population used by the Registrar General comprises all ages, whereas the pneumoconiosis certification rate is based on a male population 
The certification rate of pneumoconiosis of both the simple and complicated types in the four main Scottish coalfields runs fairly parallel to the death rates for respiratory tuberculosis and respiratory infections in the same area. Before 1936 Ogle (1885) and Tatham (1897) commented on the low tuberculosis mortality among coal miners. Many other observers have confirmed their statements and scientists have sought an explanation. Gardner (1933) demonstrated that "coal dust inhibits the growth of the tubercle bacillus" and Cummins (1934) writes.

"The coal miner seems to escape because coal dust so modifies and detoxicates the phthisive lung lesions that the condition of tuberculosis, though present. escapes recognition and is therefore absent from the death reports on which the Registrar General's death statistics are based."

In effect the submission of these authors and many others is that infective fibrosis, massive fibrosis, or complicated pneumoconiosis represents modified tuberculosis.

Our analysis of 1,315 cases of pneumoconiosis in Scottish coal mines shows that the incidence of certification in the separate coalfields appears to be related to the tuberculosis mortality rate in the same areas. This applies equally whether the disease is simple or complicated pneumoconiosis. This then would appear to suggest that if there is some relation between coal miners' pneumoconiosis and tuberculous infection it is in inducing the disease in general rather than any particular type.

What then determines complicated pneumoconiosis? In our opinion, the period at risk is a material factor and this is reflected in the age of the patient. Stone dust may be another factor. These factors inculpate both the quantity and quality of dust. It is not claimed that we have proved that complicated pneumoconiosis is essentially due to the quantity and quality of the noxious dust cloud, but we do suggest that these are important factors hitherto diminished by the emphasis on the part played by the tubercle bacillus.

In the elucidation of the aetiology of pneumoconiosis this complex problem of the separate or combined roles of dust and the tubercle bacillus is the greatest challenge to the experimental pathologists. Though as yet we do not know the answer, the control of airborne dust demands the unremitting attention of all engaged in mining coal (Bryan, 1949, 1950a and b ; Meiklejohn, 1950).

Summary

The occurrence of pneumoconiosis in the Scottish coalfields is examined by a study of all the cases $(1,315)$ certified in this area under the Coal Mining Industry (Pneumoconiosis) Compensation Scheme,
1943, and the National Insurance (Industrial Injuries) Act, 1946, during the six years 1944 to 1949.

The geographical and geological features of the area are briefly described.

Pneumoconiosis has been recognized in each of the four main Scottish coalfields and in all colliery districts within these. Since 1944 the number of certifications on account of the disease has substantially increased in the Scottish area and in each of its coalfields.

There is evidence that there has been an increase of cases of the "silicotic" type indicating a real increase in the actual occurrence of the disease within recent times. The broader scope of recent legislation, the retirement of older and unfit miners, the closure of pits, and increased radiological facilities are thought to have contributed to the progressive incidence of certifications in the years under review.

The increase is not uniform in the separate coalfields and local features which may have influenced these differences are discussed. The main factors which would appear to determine a high certification rate in an area are local underground conditions such as dry workings, thin seams, and frequent faulting with the intrusion of stone into the production area.

From an analysis of cases which could reasonably be attached to individual pits, it is submitted that there is no reliable evidence which would justify the common allegation that certain pits are "bad."

The 1,315 certifications have been examined in relation to age and the degree of disability arising from the disease. Certified cases have seldom occurred under 41 years of age, which is roughly the equivalent of 21 years of colliery work. In this matter age reflects fairly accurately the length of exposure in years to the dust risk.

It is concluded that the degree of disablement advances with age. It is further shown that complicated pneumoconiosis, a more advanced type of the disease than simple pneumoconiosis, is more common in the older age groups and that this form of the disease is invariably associated with some degree of disability and is at the same time the most common cause of total incapacity for work.

The certifications have been reviewed in relation to special occupational groups and the age of workmen in these groups.

The possible relationship of pneumoconiosis to tuberculous infection is discussed, and it is revealed that the certification rates of pneumoconiosis in the Scottish coalfields appear to be related to the mortality rates from tuberculosis of the lungs in the same geographical areas. 
I gratefully acknowledge my indebtedness to Dr. C. L. Sutherland, C.B.E., and my colleagues of the Pneumoconiosis Medical Panels, to Dr. A. Meiklejohn of the University of Glasgow, and to others for helpful advice ; also to Dr. A Massey, C.B.E., Chief Medical Officer, Ministry of National Insurance, for permission to publish this paper.

\section{REFERENCES}

Bryan, A. M. (1949). Report of H.M. Chief Inspector of Mines for 1947. H.M.S.O., London.

- (1950a). Report of H.M. Chief Inspector of Mines for 1948. H.M.S.O., London

H.M.S.O., London.
(1950b). Trans. Inst. Min. Engrs., 109, 875.

Coal Mining Industry (Pneumoconiosis) Compensation Scheme (1943). Statutory Rules and Orders, 1943 No. 885. H.M.S.O., London.

Cochrane, A. (1951). The Application of Scientific Methods to Industrial and Service Medicine, p. 97. Medical Research Council, London.

Cummins, S. L. (1934). Amer. Rev. Tuberc., 29, 17.

Davies, I., and Mann, K. J. (1949). Proc. 9th int. Congr. Industr. Med., London, 1948, p. 768. Wright, Bristol.
Fletcher, C. M. (1948). Brit. med. J., 1, 1015, 1065.

(1950). Proceedings of the Third International Conference on Pneumoconiosis, Sydney, Australia, 1950. International Labour Office, Geneva. In the press. Medicine, 6, 168 .

168. T. W. Memorar , L. U. (1933) quoted by Davies, T. W. Memorandum on Industrial Pulmonary Fibrosis. King Edward VII Welsh National Memorial Association, Cardiff, 1940.

Gilson, J. C. (1951). The Application of Scientific Methods to Industrial and Service Medicine, p. 101. Medical Research Council, London.

Gough, J. (1949). Postgrad. med. J., 25, 611.

Jenkins, T. H. (1948). Proc. S. Wales Inst. Engrs., 64, 39.

McCallum, R. I. (1952). British Journal of Industrial Medicine, 9, 99. Meiklejohn, A. (1950). Ibid., 7, 105 .

National Insurance (Industrial Injuries) Act, 1946

Ogle, W. (1885). Decennial Supplement to the Report of the Registrar General.

Scottish Home Department (1944). Scottish Coalfields : Report of the Scottish Coalfields Committee. H.M.S.O., Edinburgh.

Registrar General for Scotland (1936). Supplement to the SeventyEighth Annual Report, Part 2; General Tables. H.M.S.O. Edinburgh.

Sutherland, C. L. (1949). Postgrad. med. J., 25, 650.

Tatham, J. (1897). Decennial Supplement to the Report of the Registrar General.

\section{A P P E N D I X}

\section{A : Central Coalfield (Lanarkshire Basin, Douglas Valley, and N.E. Stirlingshire)}

A1. Northern Lanarkshire : Cadder, Chryston, Kilsyth, Twechar, Falkirk, Denny, Larbert, Stirling, and Bo'ness districts.

A2. Central Lanarkshire : Airdrie, Coatbridge, Bellshill, Cambuslang, Uddingston, Hamilton, Motherwell, Wishaw, and Larkhall districts, and the Douglas district.

A3. Shotts and Wilsontown.

A4. West Lothian and West Midlothian : Bathgate, Armadale, and Whitburn districts.

\section{B : Fife and Clackmannan Coalfield}

B1. Clackmannan and West Fife: Clackmannan, Comrie, and Valleyfield districts.

B2. Central Fife : Dunfermline, Cowdenbeath, and Lochgelly districts.

B3. East Fife : Kirkcaldy, Wemyss, and Leven districts.

\section{C : Lothians Coalfield (Mid and East Lothian)}

C1. Midlothian : Musselburgh, Dalkeith, and RoslinLoanhead districts.

C2. East Lothian : Prestonpans, Tranent, and Ormiston districts.

\section{D : Ayrshire Coalfield including Sanquhar-Kirkconnel Basin in Dumfriesshire}

D1. Central Ayrshire : the larger, and economically the more important, comprising Mauchline, Cumnock, New Cumnock, Annbank, and Dalmellington districts.

D2. Other Ayrshire coal workings comprising North Ayrshire (Dreghorn and Kilmarnock districts), South Ayrshire (Dailly district) and Dumfriesshire (Sanquhar and Kirkconnel districts). These lie in different directions on the periphery of the Central Ayrshire area and are included in one area as individually they do not employ a sufficient number of workers to provide units of reasonable size for analysis.

These four main divisions and their sub-divisions have been so defined as they are natural geographical units of reasonable size and conform closely to the arrangement in the Scottish Coalfields Report. 